\title{
Cash limits curb Max Planck Society's plans in the east
}

Munich. Plans to set up a full complement of Max Planck research institutes in east Germany by the end of the century are likely to be delayed because of a lack of funds. The Max Planck Society (MPS) says this is because the federal government's promise of a five per cent annual grant increase will, in practice, be worth only half that amount.

The MPS has already created ten research institutes in the new Länder, and had been hoping to increase this to between 15 and 18 by 2000, an equivalent research strength within the Max Planck system to that of the old Länder of west Germany.

This goal of regional balance represents something of a compromise for the research organization, which usually rejects demands for juste retour - the idea that benefits should be divided between sponsors according to the size of their contribution.

Although its funding is shared equally between the federal and Länder governments, the MPS normally argues for the right to establish research institutes wherever the appropriate supporting academic strengths - for example, in university departments - already exist. But an exception was made after reunification because of the need to establish a strong research environment in the new Länder.

The MPS was initially criticized for its apparent slowness in establishing itself in the east. As its research activities are distributed over the whole of Germany, it was reluctant merely to take over institutes of the former East German Academy of Sciences - only two of the new institutes are based on research being carried out prior to reunification. Instead, it picked new research areas to complement its overall activities, and then, after taking geographical balance into account, reached agreement with local universities and other research establishments in east Germany, to build up their research strengths in these areas.

But this plan depends on a renewal of the so-called 'five-by-five' agreement under which both the Max Planck Society and the grant-giving agency, the Deutsche Forschungsgemeinschaft (DFG), were guaranteed a five per cent increase in funding for each of the five years 1991 to 1995 . But the government, faced with economic recession, has been reluctant to agree to this.

The federal finance ministry has agreed with Jürgen Rüttgers, the research minister, on a five per cent increase for both organizations next year, and to plan for the same increase for the following three years. This proposal will go to the Länder governments next month, and, if approved, to the federal parliament before the end of the year.

The DFG is pleased with this arrange- ment. But the MPS believes that it has been short-changed. Wolfgang Hasenclever, general secretary of the MPS, claims that the government's offer to the MPS represents only a 2.5 per cent increase over its budget for the current year - and that this will leave it with DM200 million (US\$143 million) less than it needs to realize its plans.

According to Hasenclever, the difference has arisen because the government based its calculation on a budget for the MPS that excluded money allocated to the establishment of social sciences centres which will be taken over by universities next year. The MPS argues this sum belongs within their basic budget, but the research ministry says their expenses must be considered separate.

The government adds that it recognizes the MPS's need for money for new buildings. But the MPS says that this amounts at most to a noble, but as yet unfulfilled promise. The organization has not been

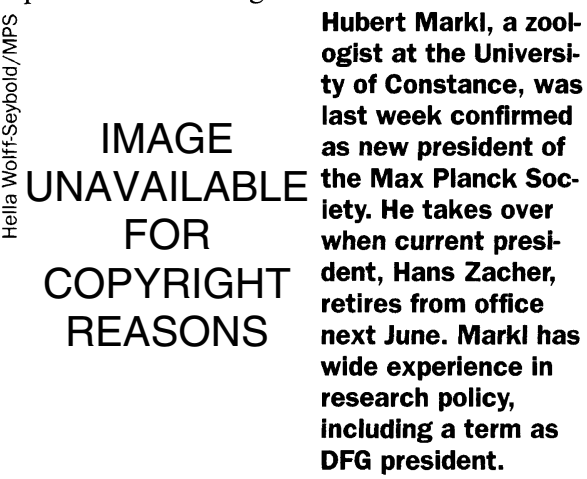

offered any additional infrastructure funds next year, and although DM7 million has provisionally been included in the plan for 1997 and 1998, this will be renegotiated in the light of the situation then facing the MPS when budgets for these two years are fixed. It is also only one-third of the money that the MPS had planned for building-work during these years.

Acknowledging that Germany is one of the few countries that are actually increasing their research budgets, Hasenclever says that the MPS is accepting the situation, albeit reluctantly. Indeed, a delay in its plans may not be as serious as the MPS claims, as the organization has itself had difficulty in meeting its timetable for building up research institutes in the east where it has had recruiting problems.

Of the ten institutes already founded, only three have their full complement of scientific directors. "It has been difficult to persuade people to go [to east Germany] because the social conditions are so poor, particularly schooling", says Hasenclever. "You really need people with a pioneering spirit."

Alison Abbott

\section{Panel clears professor involved in studies of 'close encounters'}

Boston. Harvard University has decided not to take any disciplinary action against John Mack, a professor of psychiatry at the medical school who has been carrying out studies of individuals claiming to have been abducted by extraterrestrial beings.

The university announced its decision last week after the completion of a year-long investigation of the author of the bestselling book, Abduction: Human Encounters with Aliens. "The process is over," said Anne Taylor, counsel for the university. "John Mack is in good standing as a member of the Harvard faculty."

Until now, the very existence of a committee appointed by Daniel Tosteson, dean of the medical school, to review Mack's UFO-related research had been kept secret. Indeed, the university did not officially confirm a review panel had been set up until the inquiry had been completed and the panel disbanded.

The university has now confirmed that the faculty committee was chaired by Arnold Relman, professor emeritus at the medical school and former editor of the $\mathrm{New}$ England Journal of Medicine, and had been charged with looking into the "clinical care and clinical investigation" that Mack had carried out with those claiming to have been abducted by UFOs.

There had been concern, in particular, over whether Mack had been attempting to treat such individuals, or to study them, and over whether he had secured the formal permission needed to conduct research on human subjects.

According to Keren McGinty, a spokesperson for the medical school, Tosteson had emphasized to Mack that, in his enthusiasm to care for and study this group of individuals, "he should be careful not in any way to violate the high standards for the conduct of clinical practice and clinical investigation that have been the hallmark of this faculty".

Critics of the closed-door inquiry, some of whom had branded the proceedings a "witch hunt", had expressed fears that Mack's academic liberties were being trampled on. But according to McGinty, Tosteson confirmed that Mack was free "to study what he wishes and to state his conclusions without impediment".

At the same time, although Mack's academic freedom has been upheld, many feel that he has also been served public notice that his work must conform to stringent standards of both scholarship and medical practice. Neither Mack nor his lawyer, Eric MacLeish, has commented on the university's decision to set up a review committee, or on its outcome. Steve Nadis 